УДК 78.071.1(410)

DOI: https://doi.org/10.33643/kmus.2019.58.08

Ольга Петрова, кандидат мистецтвознавства, доиент кафедри історії музики Київської муніципальної академії музики ім. Р. М. Глієра https://orcid.org/0000-0002-3530-2792 vantomu@yahoo.com

Olga Petrova, Ph.D. in Arts, Associate Professor at the Department of Music History, R. Glier Kyiv Municipal Academy of Music, https://orcid.org/0000-0002-3530-2792 vantomu@yahoo.com

\title{
ТВОРЧА ДІЯЛЬНІСТЬ Х'ЮБЕРТА ПЕРРІ В КОНТЕКСТІ АНГЛІЙСЬКОЇ МУЗИЧНОЇ КУЛЬТУРИ КІНЦЯ ХІХ - ПОЧАТКУ ХХ СТ.
}

Статтю присвячено розгляду творчої постаті видатного діяча англійської музичної культури кінця XIX - початку XX ст. Х'юберта Перрі, що стояв біля витоків епохи нового національного музичного відродження. У роботі виявлено різні грані творчої особистості митця просвітника, науковця, викладача, композитора; доведено, що його творча діяльність мала колосальний вплив на процеси формування національної композиторської школи. Виявлено пріоритетні жанрові сфери творчості Перрі, роль національних музичних традицій у ній; дано характеристику обраних творів композитора; наведено важливі свідчення британських музикознавців щодо різних аспектів творчості та особистості митця.

Ключові слова: Х'юберт Перрі, англійська музична культура, національна композиторська школа, художньо-культурний контекст.

Petrova Olga. Hubert Parry's creative activity in the context of the English musical culture at the end of XIX - beginning the XX centuries. The purpose of the work is to discover the significance of the Hubert Parry's creative activity in the historical context of the process of the formation of a new national composing school of Great Britain at the turn of the nineteenth and twentieth centuries. The methodology of the work consists in the application of historical-cultural, art criticism, analytical, comparative methods, which make it possible to explore the ideological and aesthetic content of Parry's creative activity, to analyze the genre-style orientation of the composer's work. Contextual and systemic methods make it possible to study it in the direct inclusion in the integrity of culture, in the system of its organic interconnections. 
The scientific novelty of the work is that for the first time in Ukrainian musicology it covers the creative personality of Hubert Parry, an outstanding figure in English musical culture of the late XIXth - early XXth century, who was at the beginnings of the era of new national musical revival. Conclusions. The work revealed various facets of the Parry's creative personality - the enlightener, scientist, teacher, composer; it is proved that his creative activity had a tremendous influence on the processes of the formation of the national composing school. The priority genre spheres of Parry's creativity, the role of national musical traditions in it are revealed; the characteristics of selected works of the composer are given. His creative contacts with his contemporaries, the outstanding representatives of the English musical culture of the Victorian era, are highlighted; the important testimonies of British musicologists on various aspects of the artist's creation and personality are given in the article.

Key words: Hubert Parry, English musical culture, national composing school, art-cultural context.

Петрова Ольга. Творческая деятельность Хьюберта Пэрри в контексте английской музыкальной культуры конца XIX - начала XX вв. Целью работы является обнаружение значимости творческой деятельности Хьюберта Пэрри в историческом контексте процесса становления новой национальной композиторской школы Великобритании на рубеже XIX-XX веков. Методология исследования состоит в применении историко-культурного, искусствоведческого, аналитического, компаративного методов, которые дают возможность исследовать идейноэстетическое содержание творческой деятельности Пэрри, проанализировать жанрово-стилевую направленность творчества композитора. Контекстный и системный методы делают возможным исследование его в непосредственном включении в целостность культуры, в систему её органических взаимосвязей. Науцная новизна работы состоит в том, что в ней впервые в украинском музыковедении освещается творческая личность выдающегося деятеля английской музыкальной культуры конца XIX - начала XX вв. Хьюберта Пэрри, который находился у истоков эпохи нового национального музыкального возрождения. Bbводы. В работе выявлены различные грани творческой личности Пэрри - просветителя, ученого, педагога, композитора; доказано, что его творческая деятельность имела колоссальное влияние на процессы формирования национальной композиторской школы. Выявлены приоритетные жанровые сферы творчества Х. Пэрри, роль национальных музыкальных традиций в нем; дана характеристика избранных произведений композитора. Освещены его творческие контакты с 
современниками - выдающимися представителями английской музыкальной культуры Викторианской эпохи; приведены важные свидетельства британских музыковедов, касающиеся различных аспектов творчества и личности художника.

Ключевые слова: Хьюберт Пэрри, английская музыкальная культура, национальная композиторская школа, художественно-культурный контекст.

Друга половина XIX століття - особливий період в історії англійської музичної культури. Вперше після тривалої двохсотлітньої перерви в розвитку, епохи глибокого занепаду й кризи, англійська музика наближається до рівня загальноєвропейського музичного мистецтва, формуючи нову сучасну професійну композиторську школу. Особливого значення в цьому процесі набуває творча діяльність Х'юберта Перрі (18481918), фундатора й одного 3 найвизначніших представників епохи нового англійського музичного відродження. Видатний діяч англійської культури, Перрі виявив себе яскраво у різних сферах - як учений-мистецтвознавець, викладач, композитор і виконавець, чию грунтовну різнобічну діяльність було підпорядковано високій меті відродження багатовікових традицій англійської музики та створення нової національної композиторської школи.

На жаль, можемо констатувати, що творча постать Перрі до сьогодні залишається поза увагою українських музикознавців. Вкрай обмеженими $є$ уявлення про епоху, що готувала дивовижний злет англійської музики у ХХ столітті, про самовіддану багатовекторну діяльність цілої плеяди митців, спрямовану на відновлення престижу англійської музики та обгрунтування рівноправності англійської композиторської школи щодо провідних національних музичних шкіл континентальної Свропи. Єдиним джерелом інформації дотепер залишається монографія Л. Ковнацької «Англійська музика XX століття», де в першому розділі першої частини («Витоки нового руху») дається лаконічний огляд творчості Х. Перрі та Ч. Стенфорда, своєрідний «подвійний» портрет композиторів. Отже, у зверненні до вищезазначених питань полягає актуальність і новизна проблематики статті. У зв’язку з цим, метюю їі стає виявлення значущості творчої діяльності X'юберта Перрі, її масштабності та багатовекторності в історичному контексті процесу становлення нової національної композиторської школи Великобританії на межі XIX-XX століть. Методологія дослідження полягає в застосуванні історико-культурного, аналітичного методів, які надають можливість дослідити ідейноестетичний зміст творчої діяльності Перрі, проаналізувати жанровостильову спрямованість творчості митця. Контекстний і системний методи 
уможливлюють дослідження іiі в безпосередньому включенні в цілісність культури, у систему іï органічних взаємозв’язків.

Творча діяльність X'юберта Перрі розгорталася у так званий вікторіанський період (тривала доба правління королеви Вікторії, 18371901), що був ознаменований розквітом багатьох сфер англійської культури. Саме в цей період Великобританія набуває статусу великої колоніальної держави, формує національну ідею та ідентичність. Вікторіанство як феномен культури, в якому активно вибудовувалася концепція національного характеру, залишило у свідомості британців певне уявлення про непорушність традицій, соціальну стабільність, значущість демократії та моральної філософії. I дійсно, саме вікторіанські письменники своєю творчістю довели неминуще значення духовних цінностей у формуванні національного менталітету та визначенні місця індивідууму в історії та цивілізації. Друга половина ХІХ століття - доба розквіту англійської літератури, пов’язана з творчістю «блискучої плеяди» британських письменників: В. Теккерея та Ч. Діккенса, Д. Мередіта й В. Коллінза, Е. Троллопа й Дж. Еліота, Е. Гаскелл і Т. Харді.

Інша ситуація складалася у музичному мистецтві Великобританії цієї доби. 3 одного боку, бурхливий розвиток концертного життя й побутового музикування створювали враження розквіту, здавалося, що «насичення» музикою досягло свого апогею. Одна за одною виникають нові концертні організації широкого суспільного значення: «Крістел Пелес», під керівництвом А. Манна та Дж. Гроува, «Сент-Джеймс Холл», симфонічний оркестр під орудою Ч. Халле. Ці концертні товариства, у яких репертуар вже не обмежується ораторіальною хоровою музикою, дають можливість англійській публіці познайомитися 3 новими симфонічними й камерними творами. Активізація концертної діяльності, розвиток музичної журналістики, збагачення оперного репертуару - все це, безумовно, були позитивні зсуви, що свідчили про наближення нового періоду, згодом визначеного британськими мистецтвознавцями та істориками як «епоха музичного відродження», а також відображали загальноєвропейські процеси боротьби за музичне просвітництво, що посилилися в 60-х роках XIX ст.

Але водночас загальний рівень національної професійної музичної культури, відсутність серйозної композиторської школи викликали неабияке занепокоєння англійських музикантів. За словами Л. Ковнацької, «завершувався тривалий процес переродження, якісного зсуву музичної культури в інший ряд - стабілізована традиція слухацького сприйняття подолала згасаючу традицію професійної школи, i взяла гору легка розважальна музика» [1, с. 55]. Музиканти відчували серйозну небезпеку в 
пануванні на театральних сценах комедійних «баладних» оперних зразків, на концертній естраді - салонних балад, у появі нового розважального жанру оперети та його надзвичайному успіху в публіки. Ситуація, за якої головними здобутками й гордістю національного театру стали фарс, феєрія та комічна опера, не могла залишати байдужими представників культурної еліти британського суспільства. Отже, потреба у відродженні національної композиторської школи, активізації професійної музичної культури поставала в цей час особливо нагальною.

X'юберт Перрі народився у Борнмуті в аристократичній родині. Його батько, сер Гембір Перрі, колекціонував італійські твори образотворчого мистецтва, сам займався живописом, а також був талановитим музикантом-аматором, грав на фортепіано й валторні. Під впливом батька та директора школи Хемпшира, у якій X'юберт навчався 31858 року, він захоплюється музикою і починає займатися нею в Семюеля Уеслі та Едварда Брінда, місцевих церковних органістів. Згодом Перрі, згідно 3 сімейною традицією, продовжує освіту в Ітоні. Його вчителем музики там став теж органіст, Джордж Елві, який навчав основам контрапункту та оркестровки, знайомив учня зі струнними квартетами Гайдна й Моцарта, оркестровими творами Бетховена, Вебера та Мендельсона. У цей час зацікавлення Перрі музикою «виросло настільки, що його вже не можна було ігнорувати чи зневажати...», - зазначає біограф композитора Д. Дайбл [4, с. 32].

Склавши 1867 року іспит на ступінь бакалавра музики в Оксфорді ${ }^{1}$, Перрі вступає до університету, де навчається у найкращих музикантів того часу - Джорджа Макфаррена та Стендла Беннета, а під час літніх канікул продовжує навчання у Штутгарті в Генрі Пірсона. Після закінчення університету, Перрі вдосконалює композиторську майстерність, беручи уроки в Едварда Даннройтера ${ }^{2}$; саме він знайомить учня з творами Ріхарда Вагнера, вплив якого виявляється в композиціях Перрі даного періоду. Не менш важливого значення у процесі творчого становлення митця набуває вивчення музики Брамса, що розпочалося зі знайомства з Варіаціями на тему Генделя. Отже, і в Англіі, і поза іiі межами композитора орієнтували перш за все на засвоєння традицій німецької музичної культури, що стало досить міцним підгрунтям його творчості.

\footnotetext{
${ }^{1}$ Екзаменаційна робота Перрі, кантата «O Lord, Thou hast cast us out» («Господи, ти вигнав нас»), отримала схвальну оцінку професора музики сера Ф. Уізлі й була тріумфально виконана та опублікована 1867 року.

${ }^{2}$ Едвард Даннройтер - відомий музикант, науковець, піаніст і диригент, засновник Вагнерівського товариства (1872) та Вагнерівського фестивалю (1877) у Лондоні. Був першим виконавцем фортепіанного концерту Перрі.
} 
Активна громадська діяльність Перрі на батьківщині призвела до створення 1883 року першого власне музичного вищого навчального закладу в Лондоні - Королівського коледжу музики, провідним викладачем якого він стає (3 1883 р. - професор композиції та історії музики, 31894 р. - директор закладу). Упродовж багатьох років композитор обіймає також посаду професора Оксфордського університету. Його лекції з історії музики справляли надзвичайний вплив на студентів, що захоплювалися широкою ерудованістю професора, нестандартністю його мислення, вмінням блискуче висвітлювати мистецькі явища в широкому історичному контексті. Серед учнів Перрі - відомі згодом музиканти, провідні композитори наступного покоління: Ф. Брідж, Д. Айленд, А. Самервел, Р. Воан Уільямс, Г. Холст. Усі учні високо цінували його і як композитора, і як учителя. «Таємниця величі Перрі як учителя, - згадував Р. Воан Уільямс, - полягала в його широкій прихильності: це не була так звана широта поглядів, яка виникає через відсутність переконання; його музичні антипатії були дуже сильними, а іноді, на думку тих, хто з ними не погоджувався, необгрунтованими; але оцінюючи твори композитора, він був здатен встановити їх з одного боку та побачити поза їх межами. I саме в цьому дусі він аналізував роботу своїх учнів. Композиції студента рідко мають яку-небудь художню вартість, і вчитель може судити про них за їхньою особистою цінністю. Але Перрі дивився далі; він бачив, що ховається за помилковим висловленням і ставив за мету усунення перепон, що заважали повноті музичної мови» [9, с. 296]. Покоління студентів потрапили під чари його шляхетної, щедрої особистості та перейнялися ідеями вчителя, зокрема щодо моральної відповідальності митця перед суспільством. Е. Елгар висловлював широку суспільну думку, коли в лекції 1905 року назвав Перрі «головою нашого мистецтва в цій країні» [3].

$\mathrm{X}$ 'юберт Перрі є автором багатьох грунтовних наукових праць, що, поза сумнівом, були відображенням серйозної педагогічної роботи, яку вів композитор. 1886 року з'явилося перше фундаментальне дослідження «Studies of Great Composers», де в широкій історичній перспективі розглядається творчість визначних митців минулого та сьогодення (від Палестрини до Брамса й Вагнера). Проблемам розвитку музичного мистецтва присвячено дві фундаментальні роботи Перрі: «The Evolution of the Art of Music» (1896) та «Summary of the history and development of mediaeval and modern European music» (1905). Сферою особливої зацікавленості та уваги митця завжди була епоха бароко, розгляду якої присвячено дослідження «The Music of the Seventeenth Century» (1902) та 
«Johann Sebastian Bach: the Story of the Development of a Great Personality» (1909). Своєрідним підсумком багаторічної педагогічної діяльності композитора стала видана 1911 року робота «Style in Musical Art», основу якої склали його лекції.

Важливою сторінкою науково-просвітницької роботи Х'юберта Перрі було також написання статей ${ }^{1}$ (усього 123) для авторитетного до сьогодні музичного словника, головним редактором та упорядником якого був Джордж Гроув (1820-1900) - колега та близький друг композитора. Слід зазначити, що за життя Перрі мав тісні творчі контакти з багатьма визначними особистостями, своїми сучасниками. Він зустрічався 3 Р. Вагнером, Й. Брамсом, листувався 3 А. Рубінштейном. 3-поміж співвітчизників теплі дружні стосунки та, водночас, глибока духовна спорідненість пов'язували Перрі 3 А. Кольріджем, фундатором прославленого бахівського хору, що вперше представив у Лондоні визначні творіння німецького композитора, та Ч. Стенфордом, видатним вченим-просвітником та музикантом. Спільними зусиллями митцям вдалося змінити сучасні погляди на роль і завдання музичного мистецтва у суспільстві, підняти соціальний статус професійної національної композиторської школи. Перрі та Стенфорд ініціювали численні просвітницькі заходи в Лондоні, брали безпосередню участь у всіх прогресивних починаннях свого часу, були засновниками різних музичних фестивалів, товариств і об'єднань. Стенфорд із особливою пошаною висловлювався про творчі здобутки свого друга й колеги. Він був одним із перших британських музикантів, що спромігся розпізнати талант Перрі, оцінював його як «найвеличнішого англійського композитора 3 часів Перселла» [4, с. 165].

1880 року з'явилися перші значні твори митця - фортепіанний концерт і хорові сцени за «Звільненим Прометеєм» П. Б. Шеллі. Прем’єрне виконання останніх мало знаменувати початок «відродження» в англійській музиці, але деякі критики оцінили його як занадто авангардне. Справжнє визнання прийшло до композитора з успіхом наступного твору, яким стала ода для хору та оркестру «Блаженна пара Сирен» (1887) на текст вірша Джона Мільтона «На урочистій музиці», присвячена Ч. Стенфорду. Х'юберта Перрі було визнано провідним британським хоровим композитором свого часу.

\footnotetext{
${ }^{1}$ Вагомий вплив даних статей Перрі на своє становлення як композитора відзначав Едвард Елгар, що не відвідував музичний коледж, а отже не мав традиційної професійної освіти.
} 
I насправді внесок митця в сферу хорової музики, що протягом століть була найяскравішим репрезентантом національної музичної традиції, був надзвичайно вагомим. Перрі грунтовно підходить до вибору літературних текстів для своїх хорових творів, що завжди мають високі художньо-поетичні якості, $\epsilon$ актуальними та сучасними, спираються на національні джерела. Значним досягненням митця є ораторії, створені на біблійні й міфологічні сюжети: «Юдиф» (1888), «Іов» (1892) та «Цар Саул» (1894). Ораторіальний жанр видавався композитору найбільш актуальним, він прагнув наповнити його філософською проблематикою, надати йому сучасного й водночас універсального сенсу. Хорову творчість також яскраво представляють Оди для хору з оркестром $(1885,1887)$ та Оди для солістів, хору й оркестру (1889, 1891), збірка псалмів «De Profundis» (1891), а також дві «Сакральні симфонії» для хору 3 оркестром (1904, 1906). Особисті гуманістичні переконання Перрі призвели його до створення циклу із шести «етичних кантат», експериментальних творів, які, як він сподівався, згодом витіснять традиційні форми кантати й ораторії. Деякими з них («Видіння життя», 1907; «Викуп душі», 1906) особливо захоплювався Едвард Елгар.

Важливе місце у творчості композитора посідають «Пісні прощання», цикл із шести хорових мотетів, створений протягом 1916-1918 років, незадовго до смерті, в основі якого - вірші британських поетів та текст із Псалтиря, знайдений у «Book of Common Prayer» 1662 року. Пісні створювалися композитором під час Першої світової війни, коли багато його учнів, що навчалися в Королівському музичному коледжі, загинули на фронті. Будучи протягом всього життя послідовним германофілом, впевненим у тому, що конфлікт між Британією та Німеччиною $\epsilon$ неможливим, Перрі переживав велике потрясіння, період глибокого особистого відчаю та розчарування, що знайшло відбиток у шести творах циклу. Вибір текстів, очевидно, відображав прагнення уникнути насильства й жорстокості, що панували в сучасному світі, та знайти мир і спокій у душі та на небесах. Мотети даного циклу зараз становлять невід'ємну частину репертуару англіканської церковної музики та часто виконуються як антеми під час богослужіння у церквах і соборах.

Яскраво самобутньою частиною творчої спадщини Перрі є пісні, які він писав протягом усього життя та які згодом стали важливою складовою англійського вокального репертуару. Особливе місце серед них посідають дванадцять зошитів «Англійської лірики», що вміщують твори, різні за масштабом та композиційною структурою, але завжди позначені витонченим літературним смаком, глибиною музичного прочитання 
поетичних текстів, органічною єдністю фортепіанної та вокальної партії. Одна 3 найбільш відомих пісень композитора, «Єрусалим» (1916), написана на текст із поеми «Мільтон» В. Блейка, стала національним англійським гімном під час Першої світової війни й залишається ним до сьогодні. Протягом життя Перрі звертався майже до всіх існуючих жанрів, окрім опери. На думку Л. Ковнацької, «у цьому можна вгледіти вплив його пуританського виховання й поглядів i, 3 неменшими підставами, відображення особливої долі опери в Англії» [1, с. 61]. Хоча слід зазначити, що музичний театр все ж таки приваблював композитора, i яскравим свідченням того стала створена ним музика до п’єс Аристофана, поставлених у Кембриджському та Оксфордському університетах («Птахи», «Жабеня», 1892; «Хмари», 1905; «Ахарніанці», 1914), а також музика до трагедії Есхіла «Агамемнон» (Кембридж, 1900).

Важливою сферою творчості митця була оркестрова та камерноінструментальна музика, що на межі XX-XXI століть отримала друге життя, почала активно відроджуватися, звучати у виконанні різних авторитетних колективів як у Великобританії, так і поза іiі межами. Перрі є автором п’яти симфонійํㅜ, циклу Симфонічних варіацій (1897), Увертюри до «Ненаписаної трагедії» (1893), Елегії для Брамса (1897). Після прем'єрного виконання Першої симфонії композитора 1882 року авторитетний музичний критик Джозеф Беннетт у своїй статті в «The Daily Telegraph» написав, що цей твір дав «переконливий доказ того, що англійська музика досягла періоду відродження» [5, с. 88]. На думку американських дослідників Лори Кун та Ніколаса Слонімського, «оркестрова музика Перрі відіграла значну роль у розвитку британської симфонічної традиції. Хоча його оркестрові твори багато чим зобов'язані німецьким романтикам, зокрема Мендельсону, Шуману та Брамсу, тим не менш, він розробив власний стиль, що відрізняється тонкою майстерністю та колоритністю діатонічного письма. Його п’ять симфоній демонструють зростаючу впевненість у поводженні з великими формами» [11, с. 2752].

Творча діяльність Перрі була завжди досить інтенсивною та активною, майже до кожного серйозного музичного фестивалю чи свята він створював твори крупної форми. Незважаючи на це, деякі критики вважали, що творчості композитора перешкоджає його бурхлива просвітницька, виконавська й педагогічна діяльність, вона суттєво відволікає митця від його основного покликання - композиції. Так, відомий музичний критик вищезгаданого видання «The Daily Telegraph» Робін Легж писав 1918 року в офіційному некролозі на смерть Перрі:

\footnotetext{
${ }^{1}$ П’ята симфонія композитора має самостійну назву «Симфонічна фантазія 1912 року».
} 
«Композитор, що має значення, є достатньо рідкісним явищем будь-де i будь-коли. Не намагайтеся уявляти його як мікст університетського професора, кабінетного міністра, міського магната, або дюжини інших речей. Величезного удару було нанесено по англійській музиці, коли Перрі був призначений наступником сера Джорджа Гроува на посаді директора Королівського коледжу музики» [8, с. 490].

На музичний стиль Перрі суттєво вплинула, перш за все, англійська хорова традиція, композитор був одним із перших, хто звернувся до вивчення мадригальної культури XVI століття й творчості свого великого попередника Г. Перселла, яка була протягом попередніх століть майже зовсім забута. Окремою сферою зацікавленості композитора була народна творчість: він грунтовно вивчав національну вокальну та інструментальну традиції, входив до «Комітету фольклорного товариства» як його провідний діяч. У власній творчості це виявлялося не просто в цитуванні окремих музичних зразків, а у глибокому перетворенні характерних рис ладо-інтонаційної, ритмічної організації фольклорного матеріалу. Слід зазначити, що окрім національної англійської, досить значущою виявилася для митця німецька традиція, яка живила його творчість 3 ранніх років і мала достатньо широкий спектр впливу: від Букстехуде й Баха - до Брамса та Вагнера. Такі твори, як «Великий дует» для двох фортепіано, Хоральні прелюдії для органу, Партита для скрипки й фортепіано, фортепіанна сюїта «Крізь сторіччя», демонструють, «наскільки глибоко композитор засвоїв традиції XVIII століття, і наскільки майстерно він міг адаптувати їх до сучасних умов» [6, с. 305]. За словами Д. Дайбла, «музичний стиль Перрі являє собою складне ціле, що відображає асиміляцію як місцевих, так і континентальних традицій. Навчений в органній майстерні в шкільні роки та отримавши освіту в системі найстаріших університетів, він ще у вісімнадцятирічному віці повною мірою ввібрав у себе естетику англіканської церковної музики та ораторіально-орієнтований репертуар провінційних музичних фестивалів» [4, с. 165].

Майкл Алліс, аналізуючи композиційний процес Перрі, зазначає, що він підходив до нього надзвичайно грунтовно. Музикознавець детально досліджує різні етапи роботи композитора - від початкових ескізів до остаточних редакцій, зроблених у процесі репетицій і виконання творів, доповнює це важливими свідченнями самого митця, вміщеними в листах та щоденниках. У результаті Перрі постає композитором надзвичайно вимогливим до себе, що «працював довго й тяжко над новим опусом, підходячи до кожного етапу процесу створення композиції 3 високим ступенем критики та професіоналізму» [2, с. 78]. Намагаючись досягти 
бажаного результату, Перрі робив численні редакції своїх творів. Зосереджуючи увагу на внутрішній логіці музичного розвитку, часто нехтував зовнішніми моментами. Так, вважаючи «чуттєву красу оркестрового звуку не зовсім приємною» [2, с. 111], він не любив користуватися чисто тембровими ефектами, міг подвоювати партії, поєднувати голоси, не прагнув до їх індивідуалізації та протиставлення. Очевидно, подібна самообмеженість була особливістю творчого методу композитора, із притаманною йому благородною стриманістю вираження.

Після смерті Перрі був незаслужено забутий, за словами сучасних британських музикознавців, через низку прикрих помилок. Було сформовано погляд на композитора як на «цілком традиційного вікторіанського джентльмена, коли насправді він має стояти в одному ряду 3 Д. Раскіном та Ч. Дарвіном як вікторіанський радикал: він був агностиком i лібералом, мав глибоку схильність до інтроспективного способу мислення» [3]. На думку Р. Морріса, «шкала цінностей Перрі набагато ближча до істини, ніж багато з нас сьогодні схильні визнавати. Між тим, давайте віддамо належне широті його мислення, інтелекту, його людській гідності, його відданості тому, що він вважав найціннішим, а також його зневажливому відкиданню всього, що $є$ просто чуттєвим або просто сенсаційним» [10, с. 103]. Репутація митця почала відновлюватися наприкінці XX століття з появою монографії Джеремі Дайбла, низки статей, присвячених його творчості, а також значної кількості записів творів композитора. 3 часом стала очевидною цінність, значущість і масштабність творчої діяльності X'юберта Перрі, що сприяла довгоочікуваному відродженню англійської національної композиторської школи, яка посіла в ХХ столітті достойне місце в ряду провідних європейських шкіл.

1. Ковнацкая Л. Английская музыка XX века. Истоки и этапы развития. Москва : Сов. композитор, 1986. 213 с.

2. Allis M. J. Parry's Creative Process. Surrey : Ashgate, 2003. 262 p.

3. Burton A. Hubert Parry Biography (BBC). URL: https://www.bbc.co.uk/music/artists/ e58a0544-2b32-47b2-955c-fa51887ec6c7 (access date: 23.05.2019).

4. Dibble J. C. Hubert H. Parry. His Life and Music. New York; London: Oxford University Press, 1992. $531 \mathrm{p}$.

5. Eatock C. The Crystal Palace Concerts : Canon Formation and the English Musical Renaissance $/ / 19^{\text {th }}$ Century Music. 2010. Vol. 34. No. 1. P. 87-105.

6. Fuller-Maitland J. A. Hubert Parry // The musical quarterly. 1919. Vol. V. No 3. P. 299-307.

7. Howells H. Hubert Parry // Music and Letters. 1969. Vol. 50. No 2. P. 223-229.

8. Legge R. H. Charles Hubert Hastings Parry // The Musical Times. 1 November 1918. P. 489-491.

9. Manning D. Vaughan Williams on Music. London : Oxford University Press, 2007. 456 p. 10. Morris R. O. Hubert Parry // Music and Letters. 1920. Vol. 1. No 2. P. 94-103. 
11. Slonimsky N., Kuhn L. Baker's Biographical Dictionary of Musicians. Vol. 4. New York : Schirmer Reference, 2001. 4500 p.

\section{References}

1. Kovnatskaya, L. (1989). English music of the twentieth century. The origins and the stages of development. Moscow: Sovetskiy kompozitor [in Russian].

2. Allis, M. (2003). Parry's Creative Process. Surrey: Ashgate [in English].

3. Burton, A. (n.d.). Hubert Parry Biography (BBC). [online]. Available at: https://www.bbc.co.uk/music/artists/e58a0544-2b32-47b2-955c-fa51887ec6c7 [Accessed 23 May 2019] [in English].

4. Dibble, J. (1992). Hubert H. Parry. His Life and Music. New York; London: Oxford University Press [in English].

5. Eatock, C. (2010). The Crystal Palace Concerts: Canon Formation and the English Musical Renaissance. 19 $9^{\text {th }}$ Century Music, 34, No 1, pp. 87-105 [in English].

6. Fuller-Maitland, J. (1919). Hubert Parry. The musical quarterly, 5, No 3, pp. 299-307 [in English].

7. Howells, H. (1969). Hubert Parry. Music and Letters, 50, No 2, pp. 223-229 [in English].

8. Legge, R. (1918). Charles Hubert Hastings Parry. The Musical Times, 1 November, pp. 489-491 [in English].

9. Manning, D. (2007). Vaughan Williams on Music. London: Oxford University Press [in English].

10. Morris, R. (1920). Hubert Parry. Music and Letters, 1, No 2, pp. 94-103 [in English].

11. Slonimsky, N., Kuhn, L. (2001). Baker's Biographical Dictionary of Musicians. Vol. 4. New York: Schirmer Reference [in English].

УДК 780.616.432.082.4+780.614.331.082.4]:78.071.1(430)

DOI: https://doi.org/10.33643/kmus.2019.58.09

Денис Кашуба, аспірант кафедри інтерпретологї та аналізу музики Харківського національного університету мистеитв імені І. П. Котляревського https://orcid.org/0000-0002-9438-2200 pianodk93@gmail.com

Denys Kashuba, Postgraduate student of the Department of Interpretation and Analysis of Music, Kharkiv National Kotlyarevsky University of Arts https://orcid.org/0000-0002-9438-2200 pianodk93@gmail.com

\section{ПЕРШИЙ ФОРТЕПІАННИЙ КОНЦЕРТ Й. БРАМСА ТА СКРИПКОВИЙ КОНЦЕРТ Р. ШУМАНА: ПРИСВЯТА ЧИ РЕМІНІСЦЕНЦІЯ?}

Актуальність теми зумовлена потребою осягнути музичні твори Й. Брамса в аспекті його «шуманіани». Мета дослідження - здійснити аналіз фортепіанного концерту Й. Брамса в контексті шуманівських ідей. У 